\title{
PENGARUH KEPUASAN KERJA TERHADAP KINERJA PERANGKAT NAGARI DALAM PENGELOLAAN KEUANGAN NAGARI DI KECAMATAN SUNGAI TARAB DAN SALIMPAUNG
}

\author{
Baiyulis \\ Jurusan Administrasi Publik, Fakultas Ilmu Sosial, Universitas Negeri Padang \\ bayyulist@yahoo.co.id \\ Syamsir \\ Jurusan Administrasi Publik, Fakultas Ilmu Sosial, Universitas Negeri Padang \\ syamsirsaili@yahoo.com

\section{Jumiati} \\ Jurusan Ilmu Administrasi Publik, Fakultas Ilmu Sosial, Universitas Negeri Padang \\ upikjumiati@yahoo.co.id
}

\begin{abstract}
The purpose of this study was to analyze the effect of job satisfaction on the performance of nagari apparatus in nagari financial management in Sungai Tarab and Salimpaung Subdistricts, Tanah Datar Regency. This study was a quantitative research with associative method. The population of this study was all nagari apparatus in the two subdistricts, Sungai Tarab and Salimpaung, which numbered 112 people. Sampling in this study used the Slovin formula and consisted of 79 nagari apparatus. Besides, sample in this study determined through proportional random technique. Data in this study were collected through questionnaires with Likert scale measurement distributed to respondents. The data obtained were then analyzed using multiple linear regression. The results of this study indicated that salaries, the work itself, co-workers, supervision, promotion and work environment, together and partially, had a significant effect on the performance of nagari apparatus in managing nagari financial in the two subdistricts. So that it could be concluded that the job satisfaction of nagari apparatus had a significant effect on the performance of nagari apparatus in nagari financial management in Sungai Tarab and Salimpaung Subdistricts, Tanah Datar Regency.
\end{abstract}

Keywords: Job satisfaction, job performance, Nagari financial management

How to Cite: Baiyulis and Syamsir. 2018. Pengaruh Kepuasan Kerja Terhadap Kinerja Perangkat Nagari dalam Pengelolaan Keuangan Nagari di Kecamatan Sungai Tarab dan Salimpaung. 2(2): pp. 73-84. DOI: https://doi.org/10.24036/jess/vol2-iss2

\section{Pendahuluan}

Lahirnya UU No. 23 Tahun 2014 tentang Pemerintahan Daerah memberikan ruang yang luas kepada pemerintah daerah untuk menjalankan urusan pemerintahan dengan prinsip otonomi seluas-luasnya. Salah satu urusan pemerintahan tersebut adalah pengelolaan keuangan. Sejalan dengan hal tersebut juga disahkan Undang-undang Desa Nomor 6 Tahun 2014 tentang Desa. Undang-undang ini menjadi landasan dalam penyelenggaraan pemerintahan desa. Dana desa/nagari menurut undang-undang ini dianggarkan oleh pemerintah untuk membiayai penyelenggaraan pemerintahan, untuk 
pembangunan, serta pembinaan kemasyarakatan, dan pemberdayaan masyarakat desa berdasarkan kewenangan dan kebutuhan desa sesuai dengan ketentuan undang-undang mengenai Desa/Nagari, yaitu UU No. 23 Tahun 2014. Dari penjelasan di atas dapat dipahami bahwa keuangan nagari dikelola dengan sebaik-baiknya secara sistematis dengan memperhatikan efektifitas penggunaannya untuk kesejahteraan masyarakat.

Selanjutnya, dalam Permendagri No 113 tahun 2014 juga disebutkan bahwa Pengelolaan Keuangan Desa/Nagari merupakan keseluruhan kegiatan yang terdiri dari perencanaan, penganggaran, penatausahaan, pelaporan, pertanggungjawaban hingga pengawasan keuangan nagari/desa. Meskipun sudah terdapat regulasi yang mengatur pengelolaan keuangan nagari, namun pada kenyataannya pengelolaan keuangan nagari masih memiliki cukup banyak permasalahan.

Permasalahan yang ditemukan dalam pengelolaan keuangan di Kabupaten Tanah Datar yaitu adanya penyelewengan atau penyalahgunaan dana Nagari. Salah satu informasi tersebut penulis temukan melalui website www.sumbartoday.com. Salah satu kasus yang terjadi akibat kesalahan dalam pengelolaan keuangan nagari adalah terjadinya penyimpangan dana proyek pada Jorong Ombilin Nagari Simawang yang terjadi karena perangkat desa atau nagari ini belum memahami cara dan sistem pengerjaan suatu proyek yang berstandarisasi Dinas Pekerjaan Umum. Permasalahan serupa juga terjadi di Nagari Sungai Jambu, Kecamatan Pariangan, Tanah Datar. Adanya permasalahan dalam pengelolaan keuangan nagari tersebut adalah indikasi kinerja yang belum baik.

Kepuasan kerja adalah hal yang penting dan harus diperhatikan dalam menentukan kinerja pegawai, karena seorang pegawai dalam menjalankan tugas dan tanggung jawabnya dipengaruhi oleh kepuasan kerja. Kepuasan kerja pegawai dapat dilihat dari sikapnya terhadap pekerjannya (Wibowo, 2013). Kepuasan kerja menjadi faktor yang mendorong agar kinerja pegawai tersebut dapat baik. Idealnya kepuasan kerja seorang pegawai harus tinggi, agar kinerjanya juga tinggi.

Namun pada kenyataannya, kepuasan kerja pegawai atau perangkat nagari di nagari-nagari yang ada di Kabupaten Tanah Datar masih rendah. Informasi yang penulis dapatkan dari beberapa nagari bahwa perangkat nagari kurang puas terhadap pekerjannya. Wawancara penulis dengan Sekretaris nagari Situmbuak tanggal 7 September 2017 mengesankan bahwa kinerja pengelolaan keuangan nagari memang belum maksimal diantaranya disebabkan oleh kurangnya kepuasan pegawai terhadap lingkungan kerja terutama karena kantor walinagarinya tidak memadai. Selain itu ia menambahkan kinerja perangkat nagari kurang maksimal karena gaji yang diterima masih di bawah upah minimum regional. Kaur Pembangunan Nagari Pasie Laweh, kecamatan Sungai Tarab mengalami permasalahan tentang ketidakpuasan kerja. Ia menjelaskan bahwa kurangnya kepuasan kerja karena kondisi kantor wali nagari yang tidak bersih, sehingga mengganggu kenyamanan kerja. Hal ini senada dengan fakta yang penulis temukan di Nagari Minangkabau bahwa kantor wali nagarinya kurang bersih dan ruangannya sempit sehingga pegawai kurang leluasa bekerja.

Menurut Yuliansyah dan Rusmianto (2017) pengelolaan keuangan desa/nagari yaitu sebuah rangkaian atau siklus yang terpadu serta terintegrasi antara satu tahapan dengan tahapan yang lainnya. Keuangan desa dikelola 
berdasarkan asas transparansi, akuntabilitas, partisipatif serta dilaksanakan dengan tertib dan disiplin anggaran. Rangkaian atau siklus dan asas tersebut harus dilaksanakan oleh setiap desa dengan sebaik baiknya, namun siklus pengelolaan keuangan desa tidak akan nerjalan dengan baik apabila tidak adanya tata pemerintahan desa yang baik (Yuliansyah dan Rusmianto, 2017). Jadi, anggaran atau dana yang ada harus dikelola dengan benar dan tentunya pengelolaan tersebut harus didukung sumber daya manusia (pengelola) yang baik dan berkualitas.

Edison dkk (2016) mengemukakan bahwa kinerja merupakan sebuah hasil yang dicapai dari suatu proses pada suatu periode tertentu dan dapat diukur berdasarkan indikator-indikator yang ada, sehingga kinerja yang optimal bukan sebuah kebetulan. Kinerja merupakan kunci dari efektivitas sebuah organisasi. Permasalahan yang terjadi dalam pengelolaan keuangan nagari salah satunya disebabkan oleh kurangnya kepuasan kerja perangkat nagari yang berdampak kepada buruknya kinerja perangkat nagari.

Dengan demikian dapat dikatakan bahwa karyawan (perangkat nagari) akan berkinerja baik apabila mereka memiliki kepuasan kerja. Dalam artian, peningkatan kepuasan kerja akan meningkatkan kinerja pegawai (Gibson dalam Wibowo, 2013). Menurut Luthans (2011), kepuasan kerja adalah keadaan emosi positif seseorang terhadap pekerjannya yang berasal dari penilaian pekerjaan ataupun pengalaman kerjanya. Indikator kepuasan kerja yang dikemukakan oleh Luthans meliputi: gaji, pekerjaan yang dilakukan, rekan kerja, pengawasan, promosi jabatan, dan lingkungan kerja. Indikator ini digunakan dalam penelitian ini untuk mengukur penyebab kepuasan kerja seorang perangkat perangkat nagari, sehingga dapat ditemukan hal-hal yang menimbulkan kepuasan dan ketidakpuasan yang pada akhirnya berdampak pada kinerja mereka dalam mengelola keuangan.

Berdasarkan informasi yang penulis dapatkan di beberapa nagari di Kabupaten Tanah Datar dapat diketahui bahwa penempatan atau pembagian tugas terhadap perangkat nagari tidak sesuai dengan keterampilan atau latar belakang pendidikan yang mereka miliki. Hal ini juga berdampak terhadap kepuasan kerjanya serta kinerjanya. Selain itu, berdasarkan wawancara penulis dengan salah seorang perangkat nagari di Nagari Tabek Patah, Kecamatan Salimpaung pada tanggal 2 Oktober 2017, pengawasan atau supervisi memiliki peranan penting terhadap perangkat nagari dalam menjalankan tugasnya akan tetapi persoalannya adalah atasannya yang seharusnya melakukan pengawasan tersebut jarang berada ditempat, kadang bersikap tidak peduli terhadap bawahannya.

Dari berbagai persoalan di atas dapat dipahami bahwa begitu banyak permasalahan yang dihadapi oleh perangkat nagari terutama dalam pengelolaan keuangan. Berdasarkan permasalahan di atas maka peneliti tertarik untuk meneliti pengaruh kepuasan kerja terhadap kinerja perangkat nagari dalam pengelolaan keuangan nagari di Kecamatan Sungai Tarab dan Salimpaung Kabupaten Tanah Datar. Penelitian ini merupakan intisari dari hasil penelitian skripsi dan merupakan bagian dari penelitian payung dari Syamsir (2017) dengan judul Model Pembinaan Aparatur Pemerintahan Nagari dalam Pengelolaan Keuangan Nagari di Kabupaten Tanah Datar. Rumusan masalah yang ingin dijawab dalam penelitian ini adalah: Apakah terdapat pengaruh kepuasan kerja terhadap kinerja 
perangkat nagari dalam pengelolaan keuangan nagari di Kecamatan Sungai Tarab dan Salimpaung?

\section{Tinjauan Kepustakaan}

\section{Kinerja}

Kinerja berasal dari kata job perfomance atau actual perfomance yaitu prestasi kerja atau prestasi yang sesungguhnya yang dicapai seseorang (Indrasari, 2017). Menurut Robbins (dalam Pasolong, 2007), kinerja adalah hasil evaluasi atau penilaian terhadap pekerjaan yang dilakukan oleh karyawan dibandingkan kriteria yang telah ditetapkan sebelumnya. Kinerja merupakan hal yang sangat penting dan harus diperhatikan oleh seluruh manajemen, baik pada tingkatan organisasi kecil maupun besar.

Kinerja dalam menjalankan fungsinya tidak berdiri sendiri, melainkan selalu berhubungan dengan kepuasan kerja karyawan dan tingkat besaran imbalan yang diberikan, serta dipengaruhi oleh keterampilan, kemampuan dan sifat-sifat individu. Sehingga dapat didefinisikan bahwa kinerja adalah hasil kerja secara kualitas dan kuantitas yang dicapai oleh seorang pegawai dalam melaksanakan tugasnya sesuai dengan tanggung jawab yang diberikan kepadanya (Mangkunegara, 2011).

Deskripsi dari kinerja menyangkut tiga komponen penting, yaitu: tujuan, ukuran dan penilaian. Penentuan tujuan dari setiap unit organisasi merupakan strategi untuk meningkatkan kinerja. Tujuan ini akan memberi arah dan mempengaruhi bagaimana seharusnya perilaku kerja yang diharapkan organisasi terhadap setiap personel. Indrasari (2017) mengemukakan bahwa karyawan akan memiliki kinerja yang baik jika mereka memiliki kepuasan kerja yang tinggi. Sehingga dengan meningkatkan kepuasan kerja dapat meningkatkan kinerja.

\section{Kepuasan Kerja}

Kepuasan atau satisfaction berasal dari bahasa latin "satis" yang artinya cukup baik atau memadai dan "factio" yang artinya melakukan atau membuat. Istilah kepuasan merujuk pada sikap umum seorang individu terhadap pekerjaannya (Sutrisno, 2012). Menurut Locke (dalam Luthans, 2011) definisi kepuasan kerja sebagai berikut: job satisfaction as involving cognitive, affective and evaluative reactions or attitudes and state it is "a pleasure or positive emotional state resulting from the appraisal of one's job or job experience" (kepuasan kerja meliputi reaksi atau sikap kognitif, afektif dan evaluatif dan memberikan pengertian bahwa kepuasan kerja adalah keadaan emosi senang atau emosi positif yang berasal dari penilaian pekerjaan atau pengalaman kerja seseorang).

Luthans (2011) mendefinisikan bahwa "job satisfaction is a result of employees' perception of how well their job provides those things that are viewed as important" (Kepuasan kerja adalah hasil dari persepsi karyawan mengenai seberapa baik pekerjaan mereka memberikan hal yang dinilai penting. Hal tersebut berupa perasaan senang atau positif atas penilaian terhadap pekerjaan ataupun pengalaman kerja pegawai tersebut, karena pekerjaan memberikan hal yang baik terhadap individu. 
Menurut teori Luthans (2011), individu akan merasa puas jika ia mendapatkan hal-hal yang penting pekerjaannya. Ia menjelaskan bahwa "it is generally recognized in the organizational behavior field that job satisfaction is the most important and frequently studied employee attitude" (Secara umum kepuasan kerja merupakan sikap yang paling penting dalam perilaku organisasi). Luthans juga mengemukakan bahwa terdapat 3 (tiga) dimensi penting dalam kepuasan kerja. Menurutnya, "there are three generally accepted dimensions to job satisfaction. First, job satisfaction is an emotional response to a job situation. Second, job satisfaction is often determined by how well outcomes meet or exceed expectations. And Third, job satisfaction represents several related attitudes".

Dengan demikian, ada tiga dimensi yang diterima secara umum untuk kepuasan kerja. Pertama, kepuasan kerja merupakan respons emosional terhadap situasi serta kondisi kerja. Dengan demikian, tidak dapat dilihat akan tetapi hanya bisa disimpulkan. Kedua, kepuasan kerja sering ditentukan oleh seberapa baik hasil yang dicapai memenuhi atau melampaui harapan. Misalnya, jika pegawai dalam sebuah organisasi merasa bahwa mereka bekerja lebih keras daripada departemen yang lain namun menerima lebih sedikit penghargaan, maka pegawai tersebut merasa tidak puas. Sehingga mereka memiliki sikap negatif terhadap pekerjaan, atasan, dan atau rekan kerja mereka. Di sisi lain, jika mereka merasa diperlakukan dengan baik dan dibayar dengan adil, mereka cenderung memiliki sikap positif terhadap pekerjaan itu. Sehingga mereka akan merasa puas. Ketiga, kepuasan kerja menggambarkan beberapa sikap yang saling terkait (pola perilaku).

Lebih lanjut Luthans (2011) mengidentifikasi dimensi kepuasan kerja dalam bentuk faktor yang mempengaruhi kepuasan kerja. Faktor-faktor tersebut dijadikan sebagai indikator dalam mengukur kepuasan kerja, yang terdiri atas 6 indikator yaitu, (1) Gaji (pay), (2) Pekerjaan itu sendiri (the work itself), (3) Rekan kerja (work group), (4) Pengawasan (supervision), (5) Promosi jabatan (promotions), dan (6) Lingkungan kerja (working conditions).

Dalam mengelola keuangan nagari dibutuhkan pengelola yang handal yang mengerti dengan tata cara pengelolaannya. Namun disamping itu, untuk mendukung kualitas kinerja dari pengelola keuangan nagari tersebut tentunya harus ada motivasi dalam menunjang kinerja mereka, salah satunya adalah dengan memberikan kepuasan kerja. Menurut Syamsir (2011) para ahli manajemen sumber daya manusia dan perilaku organisasi memberikan definisi atau konsep berbeda mengenai motivasi, namun makna yang terkandung sama, yaitu bahwa motivasi adalah keinginan, harapan, kebutuhan, tujuan, sasaran, dorongan, dan insentif; dan salah satu bentuknya adalah dorongan dalam bentuk kepuasan kerja, yang antara lain dapat dilakukan dengan memberikan imbalan yang sesuai dengan pekerjaan yang dikerjakan oleh pengelola keuangan nagari tersebut.

Di sisi lain, menurut Syamsir (2009, 2014, dan 2015) dan Syamsir dan Ali Embi (2013), motivasi sangat penting peranannya bagi orang-orang yang bekerja di sektor atau organisasi publik untuk mencapai tujuan organisasinya. Artinya pegawai yang memiliki motivasi tinggi merupakan salah satu faktor yang sangat mempengaruhi kinerja organisasi (Azhari dan Syamsir, 2012). Selanjutnya Syamsir (2016) mengemukakan bahwa umumnya teori-teori motivasi berasumsi 
bahwa motivasi sangat menentukan dan berpengaruh terhadap kinerja seseorang. Dengan demikian, pimpinan seharusnya senantiasa berfikir untuk menemukan tindakan yang tepat untuk memotivasi pegawainya; salah satu cara memotivasi pegawai adalah dengan menciptakan atau meningkatkan kepuasan kerja mereka.

Banyak penelitian yang dilakukan oleh para peneliti tentang pengaruh kepuasan kerja terhadap kinerja seseorang atau kinerja organisasi, termasuk kinerja dalam pengelolaan keuangan. Temuan penelitian tersebut menunjukkan hasil yang berbedabeda. Ada hasil yang menunjukkan dukungan terhadap teori yang ada, dan ada pula yang menentang teori yang telah ada tersebut. Temuan penelitian yang mendukung teori tersebut antara lain dibuktikan oleh hasil penelitian Febri Fuqan Artadi (2015), Titik Rosita (2016), Syamsir (2017 dan 2017) yang pada umumnya menemukan bahwa kepuasan kerja berpengaruh terhadap kinerja pegawai dalam melaksanakan pekerjaan mereka. Sementara hasil penelitian Agung Gita Subakti (2013), misalnya, menemukan bahwa kepuasan kerja tidak berpengaruh terhadap kinerja pegawai atau karyawan.

\section{Pengelolaan Keuangan Nagari}

Dalam Permendagri No.113 tahun 2014 dijelaskan bahwa pengelolaan keuangan desa adalah keseluruhan kegiatan yang meliputi perencanaan, pelaksanaan, penatausahaan, pelaporan,hinggapertanggungjawaban keuangan desa. Menurut Yuliansyah dan Rusmianto (2017) pengelolaan keuangan desa/nagari merupakan rangkaian siklus yang terpadu dan terintegrasi antara satu tahapan dengan tahapan yang lainnya. Pengelolaan keuangan Nagari/Desa antara lain juga diatur dalam Peraturan Pemerintah (PP) Nomor 47 Tahun 2015 tentang Desa. PP tersebut antara lain menjelaskan bahwa realisasi keuangan nagari paling sedikit $70 \%$ (tujuh puluh per seratus) dari jumlah anggaran belanja Desa/Nagari digunakan untuk mendanai penyelenggaraan Pemerintahan Desa, pelaksanaan pembangunan Desa, pembinaan kemasyarakatan Desa, dan pemberdayaan masyarakat Desa dan paling banyak 30\% (tiga puluh per seratus) dari jumlah anggaran belanja Desa digunakan untuk penghasilan tetap dan tunjangan kepala Desa dan perangkat Desa, operasional pemerintahan Desa, tunjangan dan operasional Badan Permusyawaratan Desa dan insentif rukun tetangga dan rukun warga.

Sesuai dengan ketentuan dalam Peraturan Menteri Dalam Negeri (Permendagri) No. 113 Tahun 2014, keuangan Desa dikelola berdasarkan berdasarkan azas-azas transparan, akuntabel, partisipatif serta dilakukan dengan tertib dan disiplin anggaran. Berikut penjelasannya:

a. Transparansi; Transparansi adalah semua kegiatan dan informasi yang berkaitan dengan pengelolaan keuangan nagari dapat diketahui dan diawasi oleh pihak-pihak yang berwenang. Sehingga tidak ada yang disembunyikan ataupun dirahasiakan.

b. Akuntabel; Akuntabel yaitu segala tindakan ataupun kinerja yang dapat dipertanggungawabkan kepada pihak yang memiliki hak untuk menerima laporan tersebut.

c. Partisipatif; Partisipatif artinya mengikutsertakan keterlibatan masyarakat umum baik secara langsung maupun melalui perwakilan rakyat dalam meyalurkan aspirasinya terutama terkait pengelolaan keuangan nagari. 
d. Tertib dan Disiplin Anggaran; Tertib dan disiplin anggaran artinya adalah bahwa pengelolaan keuangan nagari harus dilaksanakan secara konsisten dan sesuai dengan peraturan perundang-undangan yang berlaku.

\section{Perangkat Nagari}

Dalam pasal I ayat 9 Perda Kabupaten Tanah Datar Nomor Tahun 2008, dijelaskan bahwa Walinagari dan Perangkat Nagari adalah unsur penyelenggara Pemerintahan Nagari. Perangkat nagari yang peneliti maksud dalam penelitian ini adalah perangkat nagari yang sesuai dengan Pasal 6 ayat 2 yaitu terdiri dari Sekretaris Nagari dan Perangkat Nagari lainnya. Sedangkan perangkat nagari lainnya yang peneliti maksud adalah sesuai dengan yang terdapat pada Pasal 6 ayat 3(a) Perda Tanah Datar Nomor 4 tahun 2008 tentang Nagari. Dalam Pasal 6 ayat 3(a) Perangkat Nagari lainnya terdiri dari : unsur staf sekretariat nagari yang meliputi 5 (lima) urusan yaitu urusan pemerintahan, pembangunan, perekonomian, kesejahteraan rakyat serta umum dan keuangan.

Penjelasan terkait Perangkat Nagari akan dijelaskan sesuai dengan Perda Kabupaten Tanah Datar Nomor 4 tahun 2008 sebagai berikut:

a. Sekretaris Nagari; Sekretaris Nagari merupakan Pegawai Negeri Sipil yang telah memenuhi persyaratan tertentu dan kemudian diangkat oleh Sekretaris Daerah sesuai dengan peraturan-perundangan. Sekretaris Nagari sebagai perangkat nagari harus menjalankan tugas dan fungsi sesuai peraturan perundang-undangan (pasal 14 Perda Tanah Nomor 4 tahun 2008).

b. Perangkat Nagari Lainnya; Perangkat nagari lainnya yang peneliti maksud adalah sesuai dengan yang terdapat pada Pasal 6 ayat 3(a) Perda Tanah Datar Nomor 4 tahun 2008 tentang Nagari, yang terdiri atas unsur sekretariat nagari yang meliputi 5 (lima) urusan, yaitu: 1) Urusan pemerintahan, 2) Urusan pembangunan, 3) Urusan perekonomian dan kesejahteraan rakyat; 4) Urusan umum; dan 5) Urusan keuangan

\section{Metode Penelitian}

Penelitian ini menggunakan pendekatan kuantitatif dengan jenis penelitian asosiatif. Penelitian ini dilaksanakan pada beberapa kenagarian di Kecamatan Sungai Tarab dan Kecamatan Salimpaung, Kabupaten Tanah Datar. Yang menjadi variabel penelitian adalah kepuasan kerja dan kinerja pengelolaan keuangan nagari. Populasi dari penelitian ini adalah 525 orang. Sampel penelitian diambil dengan menggunakan rumus Slovin dengan teknik sampling yaitu proportional random sampling, sehingga didapatkan sampel sebanyak 228 orang.

Pengumpulan data dalam penelitian ini dilakukan dengan menggunakan angket (kuesioner). Item pernyataan dalam kuesioner penelitian ini dibuat dengan menggunakan skala pengukuran Likert. Data yang diperoleh kemudian dianalisis dengan menggunakan teknik regresi linear berganda. Setelah dianalisis maka hasiol analisis diinterpretasikan dan dibahas dengan menggunakan teori yang telah dikemukakan dalam kajian kepustakaan.

\section{Hasil Penelitian dan Pembahasan}


Dari hasil pengolahan data penelitian kemudian dilakukan uji regresi, setelah sebelumnya dilakukan uji asumsi regresi, untuk mengetahui apakah variabelvariabel independen secara keseluruhan atau simultan berpengaruh sigifikan terhadap variabel dependen yang menggunakan derajat kepercayaan 0,05 (5\%). Setelah dilakukan pengolahan data, maka diperoleh hasil seperti tertera pada Tabel 1 berikut:

Tabel 1. Hasil uji kontribusi (R) Kepuasan Kerja secara simultan terhadap Kinerja Perangkat Nagari dalam Pengelolaan Keuangan Nagari

\begin{tabular}{|c|c|c|c|c|c|c|c|c|c|}
\hline \multirow[b]{2}{*}{ Model } & \multirow[b]{2}{*}{$\mathbf{R}$} & \multirow[b]{2}{*}{$\begin{array}{c}\mathbf{R} \\
\text { Square }\end{array}$} & \multirow[b]{2}{*}{$\begin{array}{c}\text { Adj.R } \\
\text { Square }\end{array}$} & \multicolumn{5}{|c|}{ Change Statistics } & \multirow[b]{2}{*}{$\begin{array}{l}\text { Durbin- } \\
\text { Watson }\end{array}$} \\
\hline & & & & $\begin{array}{l}\text { R Square } \\
\text { Change }\end{array}$ & $\begin{array}{c}\mathbf{F} \\
\text { Change }\end{array}$ & df1 & df2 & $\begin{array}{c}\text { Sig. F } \\
\text { Change }\end{array}$ & \\
\hline 1 & $.572^{\mathrm{a}}$ & .328 & .309 & .328 & 17.941 & 6 & 221 & .000 & 1.387 \\
\hline
\end{tabular}

a. Predictors: (Constant), Lingkungan Kerja, Pekerjaan itu sendiri, Pengawasan, Rekan Kerja, Gaji, Promosi

b. Dependent Variable: Kinerja Pengelolaan Keuangan Nagari

Sumber: Hasil Pengolahan Data 2018

Dari hasil pengujian $\mathrm{R}$ berdasarkan tabel di atas, dapat diketahui bahwa nilai $\mathrm{R}$ sebesar 0,572, nilai $R$ Square sebesar 0,328, dan nilai Adjusted $R$ Square sebesar 0,309. Pada analisis regresi berganda, nilai yang digunakan adalah nilai Adjusted $R$ Square. Hasil uji Adjusted $R$ Square yang menunjukkan nilai 0,309 berarti bahwa variabel gaji, pekerjaan itu sendiri, rekan kerja, pengawasan, promosi jabatan, dan lingkungan kerja berpengaruh sebesar 30,9\% terhadap kinerja perangkat Nagari dalam pengelolaan keuangan Nagari. Sedangkan sisanya 69,1\% dipengaruhi oleh variabel lain yang tidak diteliti dalam penelitian ini. Selanjutnya hasi uji signifikansi pengaruh variabel kepuasan kerja terhadap variabel kinerja pengelolaan keuangan nagari dapat pula dilihat pada Tabel 2 berikut ini.

Tabel 2. Hasil uji anova (F) Kepuasan kerja Secara Simultan terhadap Kinerja Perangkat Nagari dalam Pengelolaan Keuangan Nagari

\begin{tabular}{llrrrrr}
\hline Model & & Sum of Squares & df & Mean Square & F & Sig. \\
\hline 1 & Regression & 8.507 & 6 & 1.418 & 17.941 & $.000^{\mathrm{b}}$ \\
& Residual & 17.465 & 221 & .079 & & \\
& Total & 25.972 & 227 & & & \\
\hline
\end{tabular}

a. Dependent Variable: Rata Rata Kinerja Pengelolaan Keuangan Nagari

b. Predictors: (Constant), Lingkungan Kerja, Pekerjaan itu sendiri, Pengawasan, Rekan Kerja, Gaji, Promosi

Sumber: Hasil Pengolahan Data 2018

Berdasarkan hasil uji F pada tabel di atas dapat dilihat bahwa nilai Sig. adalah 0,000 yang mana nilai tersebut kurang dari 0,05; artinya Ho ditolak. Dengan demikian dapat disimpulkan bahwa kepuasan kerja secara simultan berpengaruh 
terhadap kinerja perangkat Nagari dalam pengelolaan keuangan Nagari, kebenaran pengaruh variabel kepuasan kerja terhadap kinerja pengelolaan keuangan nagari dalam penelitian ini dapat dipercaya sampai $100 \%$.

Selanjutnya untuk mengetahui pengaruh besarnya pengaruh dimensi variabel $\mathrm{X}$ terhadap Y secara parsial dapat pula dilihat pada Tabel 3 berikut:

Tabel 3. Ringkasan Pengaruh Variabel X terhadap Variabel $Y$

\begin{tabular}{llccc}
\hline No. & Pengaruh & R Square & $\begin{array}{c}\text { Adjusted } \\
\text { R Square }\end{array}$ & Sig. \\
\hline 1. & X1 terhadap Y & .210 & .206 & 0.000 \\
2. & X2 terhadap Y & .023 & .019 & 0.022 \\
3. & X3 terhadap Y & .039 & .035 & 0.003 \\
4. & X4 terhadap Y & .164 & .161 & 0.000 \\
5. & X5 terhadap Y & .158 & .154 & 0.000 \\
6. & X6 terhadap Y & .170 & .167 & 0.000 \\
\hline
\end{tabular}

Sumber: Hasil pengolahan data 2018

Berdasarkan Tabel 3 di atas dapat diketahui bahwa Adjusted R Square X1 terhadap Y sebesar 20,6. Adjusted R Square X2 terhadap Y yaitu 1,9, Adjusted R Square X3 terhadap Y sebesar 3,5, Adjusted R Square X4 terhadap Y 16,1, Adjusted R Square X5 terhadap Y sebesar 15,4, dan Adjusted R Square X6 terhadap $\mathrm{Y}$ sebesar 16,7. Dari hasil analisis data yang dilakukan ini secara rinci dapat diuraikan dan diinterpretasikan sebagai berikut :

1. Berdasarkan uji $\mathrm{R}$ diperoleh hasil bahwa, gaji, pekerjaan itu sendiri, rekan kerja, pengawasan, promosi jabatan, dan lingkungan kerja secara simultan (serempak) berpengaruh sebesar berpengaruh sebesar 30,9\% terhadap kinerja perangkat nagari dalam pengelolaan keuangan nagari di Kecamatan Sungai Tarab dan Kecamatan Salimpaung, Kabupaten Tanah Datar.

2. Berdasarkan uji $\mathrm{F}$ diperoleh hasil bahwa secara simultan, gaji, pekerjaan itu sendiri, rekan kerja, pengawasan, promosi jabatan, dan lingkungan kerja berpengaruh terhadap kinerja perangkat nagari dalam pengelolaan keuangan nagari di Kecamatan Sungai Tarab dan Kecamatan Salimpaung, Kabupaten Tanah Datar dengan sig 0,000.

3. Berdasarkan uji parsial diperoleh hasil bahwa, gaji memiliki pengaruh signifikan terhadap kinerja perangkat nagari dalam pengelolaan keuangan nagari di Kecamatan Sungai Tarab dan Kecamatan Salimpaung sebesar 20,6 \% dengan sig 0,000 , pekerjaan itu sendiri berpengaruh signifikan sebesar $1,9 \%$ dengan sig 0,022, rekan kerja berpengaruh signifikan sebesar 3,5\% dengan sig 0,003, pengawasan memiliki pengaruh signifikan sebesar $16,1 \%$ dengan sig 0,000, promosi jabatan memiliki pengaruh signifikan sebesar 15,4 \% dengan sig 0,000, dan lingkungan kerja berpengaruh signifikan sebesar 16,7 \% dengan sig 0,000.

Hasil penelitian ini membuktikan kebenaran dari teori yang dikemukakan oleh Vecchio (dalam Wibowo, 2013) yang menyatakan bahwa kinerja menyebabkan kepuasan kerja; dalam artian bahwa kepuasan kerja memberikan 
kontribusi atau pengaruh terhadap kinerja. Dengan demikian dapat dipahami bahwa semakin tinggi kepuasan kerja maka akan semakin baik pula kinerjanya.

Hasil penelitian ini juga semakin memperkuat dan membuktikan teori Gibson (dalam Wibowo, 2013) yang menyatakan adanya hubungan timbal balik antara kinerja dan kepuasan kerja. Di satu sisi dikatakan bahwa kepuasan kerja menyebabkan peningkatan kinerja sehingga pekerja lebih puas terhadap pekerjaannya dan pekerjaannya akan lebih produktif. Adanya kepuasan kerja yang dirasakan oleh perangkat nagari menyebabkan produktivitas kerja yang lebih baik sehingga menjadikan kinerja perangkat nagari lebih baik pula.

Kemudian Robbins (2008) juga mengemukakan bahwa hubungan antara kepuasan kerja dengan kinerja lebih tepatnya disebut sebagai mitos manajemen, sehingga sulit untuk menetapkan ke arah mana hubungan sebab akibat diantara keduanya. Namun, dari 300 studi yang dilakukan menyatakan bahwa adanya korelasi yang kuat antara kepuasan kerja dengan kinerja pegawai. Selanjutnya ditemukan bukti bahwa organisasi yang memiliki karyawan yang lebih puas cenderung lebih efektif dibandingkan organisasi yang memiliki karyawan yang kurang memiliki kepuasan kerja.

Dari hasil analisis di atas dapat dipahami bahwa kepuasan kerja memiliki pengaruh yang signifikan terhadap kinerja perangkat nagari dalam pengelolaan keuangan nagari di Kecamatan Sungai Tarab dan Kecamatan Salimpaung, Kabupaten Tanah Datar, bahkan kontribusi pengaruhnya cukup besar, yaitu 30,9\%. Hal ini juga sejalan dengan hasil penelitian dari Titik Rosita (2016) dan Febri Furqon Artadi (2015) yang juga menemukan hal yang sama dalam penelitiannya. Hasil dari penelitian tersebut menunjukkan bahwa kepuasan kerja berpengaruh langsung dan positif terhadap kinerja karyawan.

\section{Kesimpulan dan Saran}

Berdasarkan hasil penelitian dan pembahasan yang telah diuraikan sebelumnya, maka dapat disimpulkan bahwa secara parsial gaji (X1) memiliki pengaruh signifikan terhadap kinerja perangkat nagari dalam pengelolaan keuangan nagari di Kecamatan Sungai Tarab dan Kecamatan Salimpaung, Kabupaten Tanah Datar sebesar 20,6. Sementara itu, pekerjaan itu sendiri (X2) berpengaruh signifikan terhadap kinerja perangkat nagari dalam pengelolaan keuangan nagari sebesar 1,9\%. Selanjutnya, rekan kerja (X3) berpengaruh signifikan terhadap kinerja perangkat nagari dalam pengelolaan keuangan nagari sebesar 3,5\%. Disamping itu, pengawasan (X4) memiliki pengaruh signifikan terhadap kinerja perangkat nagari dalam pengelolaan keuangan nagari sebesar $16,1 \%$. Berikutnya, promosi jabatan (X5) juga memiliki pengaruh signifikan terhadap kinerja perangkat nagari dalam pengelolaan keuangan nagari sebesar $15,4 \%$, dan yang terakhir, yaitu lingkungan kerja (X6) memiliki pengaruh signifikan terhadap kinerja perangkat nagari dalam pengelolaan keuangan nagari sebesar $16,7 \%$. Kemudian secara bersama-sama atau secara simultan, pengaruh gaji, pekerjaan itu sendiri, rekan kerja, pengawasan, promosi jabatan, dan lingkungan kerja terhadap kinerja perangkat nagari dalam pengelolaan keuangan nagari di Kecamatan Sungai Tarab 
dan Kecamatan Salimpaung, Kabupaten Tanah Datar memiliki signifikansi 0,000 dengan persentase pengaruh sebesar 30,9\%.

Dari hasil penelitian menunjukkan bahwa gaji, pekerjaan itu sendiri, rekan kerja, pengawasan, promosi jabatan, dan lingkungan kerja terhadap kinerja perangkat nagari dalam pengelolaan keuangan nagari di Kecamatan Sungai Tarab dan Kecamatan Salimpaung, Kabupaten Tanah Datar berpengaruh signifikan terhadap kepuasan dengan kontribusi sebesar 30,9\%. Artinya sebesar 69,1\% sisanya belum dimaksimalkan. Dengan demikian disarankan kepada Pemerintahan terkait agar lebih memperhatikan aspek kepuasan kerja dengan sebaik-baiknya sehingga memberikan kontribusi untuk kinerja perangkat nagari dalam pengelolaan keuangan Nagari yang sesuai dengan asas dan tepat sasaran.

\section{DAFTAR KEPUSTAKAAN}

Azhari, Z., \& Syamsir, S. (2012). Pengaruh Kepuasan Kerja dan Lingkungan Kerja terhadap Motivasi Kerja PNS Sekretariat DPRD Sumatera Barat. TINGKAP, 8(1), 93-110.

http://ejournal.unp.ac.id/index.php/tingkap/article/viewFile/1773/1514

Edison, dkk. (2016). Manajemen Sumber Daya Manusia. Bandung: Alfabeta.

Febri Furqon Artadi. (2015). Pengaruh Kepuasan Kerja Dan Beban Kerja Terhadap Kinerja Karyawan Pada PT. Merapi Agung Lestari. Skripsi. Fakultas Ekonomi,Universitas Negeri Yogyakarta.

Indrasari. (2017). Kepuasan Kerja dan Kinerja Karyawan: Tinjauan dari Dimensi Iklim Organisasi, Kreativitas Individu, dan Karakteristik Pekerjaan. Yogyakarta: Indomedia Pustaka.

Luthans. (2011). Organizational Behavior: An Evidence Based Approach, Edisi ke-12. New York: McGraw Hill

Mangkunegara. (2011). Manajemen Sumber Daya Manusia. Bandung: PT. Remaja Rosda Karya.

Pasolong, Harbani. (2007). Teori Administrasi Publik. Bandung: Alfabeta.

Robbin, SP dan Judge. (2008). Perilaku Organisasi. Jakarta: Salemba Empat

Subakti, Agung Gita. (2013). "Pengaruh Motivasi, Kepuasan, dan Sikap Kerja Terhadap Kinerja Karyawan di Café X Bogor”. Jurnal Binus Business Review. Vol. 4 No. 2 November 2013: 596-606.

Sutrisno. (2012). Manajemen Sumber Daya Manusia. Jakarta: Kencana.

Saili, S. (2009). Urgensi Motivasi Pelayanan Publik dalam Rekrutmen dan Seleksi CPNS: Alternatif dalam Peningkatan Kualitas Pelayanan Publik. Jurnal Demokrasi, 8 (1).

http://ejournal.unp.ac.id/index.php/jd/article/view/1192/1027

Syamsir, M. (2011). Dampak Program Bantuan PKL Terhadap Tingkat Motivasi Pedagang Kaki Lima (PKL) di Provinsi Sumatera Barat. TINGKAP, 7(1). http://ejournal.unp.ac.id/index.php/tingkap/article/viewFile/15/14 
Syamsir dan Ali-Embi, M. (2013). Ideologi Politik dan Motivasi Pelayanan Publik di Kalangan PNS Kota Padang. TINGKAP, 9(1), 67-82. http://ejournal.unp.ac.id/index.php/tingkap/article/viewFile/2799/2346

Syamsir, S. (2014). Public Service Motivation and Socio Demographic Antecedents among Civil Service in Indonesia. BISNIS \& BIROKRASI: Jurnal Ilmu Administrasi dan Organisasi, 21(1), 1-8. http://journal.ui.ac.id/index.php/jbb/article/viewArticle/4038/3114

Syamsir, S. (2015). Public Service Motivation among Indonesian Employees: a Critical Review Toward the Psm Theory. European Journal of Social Sciences Education and Research, 5(1), 133-142.

http://journals.euser.org/files/articles/ejser_sep_dec_15/Syamsir.pdf http://doi.org/http://dx.doi.org/10.26417/ejser.v5i1.p133-142 http://journals.euser.org/index.php/ejser/article/view/778.

Syamsir, S. (2016). The Influence of Public Service Motivation on Service Quality of Civil Servants in West Sumatra Indonesia. European Journal of Economics and Business Studies, 5(1), 33-41. http://journals.euser.org/files/articles/ejes_may_aug_16/Syamsir.pdf http://journals.euser.org/index.php/ejes/article/view/522; http://dx.doi.org/10.26417/ejes.v5i1.p33-41

Syamsir. (2017). "Model Pembinaan Kapasitas Aparatur Pemerintahan Nagari dalam Pengelolaan Keuangan Nagari di Kabupaten Tanah Datar Provinsi Sumatera Barat. Laporan Penelitian. Padang: Universitas Negeri Padang.

Syamsir. (2017). "The Effect of Competence and Job Satisfaction on Job Performance of The "Nagari" Government Apparatus in Managing Village Finances in The District of Tanah Datar. Makalah diseminarkan pada Konferensi Internasional IRCEB, Malang 11-12 Desember 2017.

Titik Rosita. 2016. Pengaruh Kepuasan Kerja Terhadap Kinerja Karyawan Dengan Komitmen Organisasional Sebagai Variabel Intervening. Jurnal Ilmu dan Riset Manajemen. Volume 5, Nomor 1, Januari 2016. ISSN: 2461-0593.

Wibowo. 2013. Manajemen Kinerja. Jakarta: PT. Raja Grafindo Persada.

Yuliansyah dan Rusminato. 2017. Akuntansi Desa. Jakarta: Salemba Empat.

UU No. 23 Tahun 2014 Tentang Pemerintahan Daerah.

Undang-Undang Nomor 6 Tahun 2014 tentang Desa.

Permendagri Nomor 113 tahun 2014 tentang Pengelolaan Keuangan Desa.

Peraturan Pemerintah Nomo 47 Tahun 2015 tentang Desa.

Peraturan Daerah Tanah Datar Nomor 4 Tahun 2008 tentang Nagari.

Peraturan Daerah Tanah Datar Nomor 11 Tahun 2014 tentang Pedoman Pengelolaan Keuangan Nagari. 
Sumbartoday. 2017. "Penyelewengan dana proyek Jorong Ombilin Tanah Datar". http://www.sumbartoday.com/wali-jorang-ombilin-tanah-datar-didugalakukan-penyimpangan-proyek/. Diakses pada tanggal 1 September 2017. 